\title{
Depression, Social Phobia and Quality of Life after Major Lower Limb Amputation
}

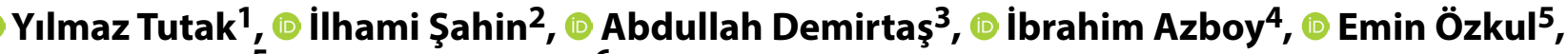 \\ Mehmet Gem ${ }^{5}$, $\odot$ Levent Adıyeke ${ }^{6}$ \\ ${ }^{1}$ Department of Orthopaedics and Traumatology, Mardin State Hospital, Mardin, Turkey \\ ${ }^{2}$ Department of Orthopaedics and Traumatology, Bismil State Hospital, Diyarbakir, Turkey \\ ${ }^{3}$ Department of Orthopaedics and Traumatology, Medeniyet University, Istanbul, Turkey \\ ${ }^{4}$ Department of Orthopaedics and Traumatology, Medipol University, Istanbul, Turkey \\ ${ }^{5}$ Department of Orthopaedics and Traumatology, Dicle University Faculty of Medicine, Diyarbakir, Turkey \\ ${ }^{6}$ Department of Orthopaedics and Traumatology, University of Health Sciences, Hamidiye Faculty of Medicine, Haydarpasa Numune \\ Health Application and Research Center, Istanbul, Turkey
}

\begin{abstract}
Introduction: In this study, we aimed to compare the social phobia, depression and quality of life in patients with major lower limb amputation to non-amputated.

Methods: Patients who were underwent above or below the knee amputation in the past were evaluated retrospectively by examining the hospital records. All the participants were administered Liebowitz Social Anxiety Scale (LSAS), Hospital Anxiety and Depression Scale (HADS), and Short-Form 36 (SF-36).

Results: The number of patients was 30 (21 males, nine females) in the amputated group and 30 (22 males, eight females) in the control group. The mean age was $41.8 \pm 14.09$ years in the amputated group and $43.3 \pm 18.68$ years in the control group. All LSAS and HADS scores were higher, and SF-36 scores were lower in the amputation group compared to the control group $(p<0.05)$. The patients who were amputated more than five years ago had higher LSAS social fear scores, and lower HAD depression scores compared to patients less than five years ( $p=0.035, p=0.024$, respectively). The employed patients had lower HAD depression and HAD total scores compared to unemployed patients ( $p=0.008, p=0,049$, respectively). The patients amputated due to medical complications had higher scores in anxiety compared to the patients with traumatic amputation ( $p=0.005, p=0.016$, respectively).

Discussion and Conclusion: Social phobia, depression and poor quality of life are common problems in patients with major lower limb amputation. After five years, it should not be forgotten that social phobia will increase; depression will decrease along with its seriousness. Therefore, amputated patients should be psychiatrically counseled and treated. It is important to provide permanent employment opportunities to improve the quality of life.
\end{abstract}

Keywords: Amputation; social phobia; depression, quality of life; psychiatry.

Conventional amputation indications include the treatment of life-threatening trauma and malignancy ${ }^{[1]}$. Major lower limb amputations remain a challenging problem. Amputated patients have problems in sleeping, con- centration, and recalling, which subsequently may lead to the development of anxiety and depression ${ }^{[2]}$. After two years of amputation, psychological problems regarding physical appearance emerge and then they may cause so-

Correspondence (Illetişim): Abdullah Demirtaş, M.D. Medeniyet Universitesi, Ortopedi ve Travmatoloji Anabilim Dali, Mardin, Turkey Phone (Telefon): +90 5055784495 E-mail (E-posta): drademirtas@hotmail.com 
cial phobia ${ }^{[3]}$. In addition, these problems may bring on negative effects on the occupational and social lives of the patients $^{[3,4]}$.

Many studies have demonstrated that physical disorders may lead to social phobia, and this could negatively affect a person's life ${ }^{[5]}$. Social and economic rehabilitation of the amputated patients is an important issue. Literature reviews have indicated that there have been very few studies evaluating the psychological parameters of amputated patients ${ }^{[6]}$. However, to our knowledge, no study has been conducted reporting the social phobia, depression and quality of life in patients with major lower limb amputation and comparing them with a control group.

In this study, we investigated the social phobia, depression and quality of life in patients with major lower limb amputation in comparison to the control group. In addition, we analyzed the subgroups concerning age, gender, cause of amputation, and time since amputation.

Our hypothesis is that in patients with major lower-extremity amputation, social phobia and depression will be a more serious and poorer quality of life when compared to the control group.

\section{Materials and Methods}

Patients who were amputated above or below the knee in the past and applied to our clinic between January 2010 and December 2013 were evaluated retrospectively in this study after approval of the local ethics committee. An informed consent was obtained from each participant. Patients older than 18 years of age who completed at least one year after amputation were included in this study. Patients who were diagnosed with psychiatric illness and/or who used the psychiatric drug during or before this study were excluded from this study. The control group was randomly selected among the persons who visited the inpatients at the hospital.

\section{Measures}

All the participants were administered Liebowitz Social Anxiety Scale (LSAS), Hospital Anxiety and Depression Scale (HADS), and Short-Form 36 (SF 36).

Liebowitz Social Anxiety Scale (LSAS): LSAS is a questionnaire developed by Liebowitz for measuring the severity of fear and avoidance in social interactions and performance situations. LSAS consists of 24 items, of which 13 items related to performance anxiety and 11 concern social situations. The scale was administered by a clinician and provided scores on six subscales that had a positive corre- lation with high scores, assessing (I) the severity of social fear, (II) the severity of performance fear, (III) the severity of social avoidance, (IV) the severity of performance avoidance, (V) severity of total fear, and (VI) the severity of total avoidance. The reliability and validity of the Turkish version of LSAS have been shown in previous studies ${ }^{[7]}$.

Hospital Anxiety and Depression Scale (HADS): HADS was first developed by Zigmond and Snaith in $1983^{[8]}$. HADS is used for assessing the severity of anxiety and depression and evaluating the risk for these disorders. HADS is suitable for patients with physical disabilities and patients presenting to first-step health centers. The scale provides scores on anxiety and depression subscales. As a patientreported instrument, HADS is a 4-point Likert-type scale. HADS includes 14 items, of which seven items relate to anxiety, and seven relate to depression. Higher scores correlate with the risk of anxiety and depression. The reliability and validity of the Turkish version of HADS were demonstrated by Aydemir et al. ${ }^{[9]}$.

Short form-36 (SF-36) Quality of Life Survey: SF-36 was developed by Ware and Sherbourne for evaluating the quality of life ${ }^{[10]}$. The questionnaire consists of 36 items assessing eight aspects of health: vitality, physical functioning, bodily pain, general health perceptions, physical role functioning, emotional role functioning, social role functioning, and mental health. These subscales are scored between 0-100, where 0 indicates poor and 100 indicates good health. The reliability and validity of the Turkish version of SF-36 were demonstrated by Kocyigit et al. ${ }^{[11]}$.

\section{Statistical Analysis}

Data were evaluated using SPSS 21.0 for Windows (SPSS Inc., Chicago, IL, USA). Statistical analyses were performed using the Mann-Whitney $U$ test and Student's t-test. A pvalue of $<0.05$ was considered significant.

\section{Results}

The number of patients was 30 ( 21 males, nine females) in the amputated group and 30 (22 males, eight females) in the control group. The mean age was $41.8 \pm 14.09$ years in the amputated group and $43.3 \pm 18.68$ years in the control group. The mean time to administer the forms after amputation was $8.77 \pm 7.92$ years.

There was no significant difference between the amputated and control group regarding age and sex $(p=0.69)$. The results of our study revealed that all LSAS and HAD scores were higher, and SF-36 scores were lower in the am- 
Table 1. Comparison of the amputated and control subjects

\begin{tabular}{|c|c|c|c|}
\hline & $\begin{array}{c}\text { Amputation } \\
(\mathbf{n}=\mathbf{3 0}) \\
\text { Group } \\
\text { Mean } \pm \text { SD }\end{array}$ & $\begin{array}{c}\text { Control } \\
\text { Group } \\
(n=30) \\
\text { Mean } \pm \text { SD }\end{array}$ & $\mathbf{p}$ \\
\hline Age & $41.86 \pm 14.09$ & $43.03 \pm 18.68$ & 0.786 \\
\hline LSAS performance fear & $19.36 \pm 4.27$ & $13.03 \pm 4.63$ & $<0.001$ \\
\hline LSAS social fear & $16.00 \pm 4.21$ & $12.53 \pm 4.43$ & 0.003 \\
\hline LSAS total fear & $35.36 \pm 7.83$ & $25.93 \pm 10.01$ & $<0.001$ \\
\hline $\begin{array}{l}\text { LSAS performance } \\
\text { avoidance }\end{array}$ & $28.73 \pm 8.43$ & $12.93 \pm 5.24$ & $<0.001$ \\
\hline LSAS social avoidance & $26.33 \pm 9.40$ & $13.03 \pm 4.55$ & $<0.001$ \\
\hline LSAS total avoidance & $55.06 \pm 17.42$ & $25.53 \pm 9.01$ & $<0.001$ \\
\hline LSAS total score & $90.50 \pm 20.66$ & $52.06 \pm 17.92$ & $<0.001$ \\
\hline HADS depression & $16.60 \pm 2.88$ & $4.50 \pm 3.18$ & $<0.001$ \\
\hline HADS anxiety & $15.86 \pm 4.00$ & $4.63 \pm 2.67$ & $<0.001$ \\
\hline HADS total & $32.70 \pm 6.30$ & $9.10 \pm 5.51$ & $<0.001$ \\
\hline SF-36 physical functioning & $58.70 \pm 17.50$ & $82.00 \pm 7.38$ & $<0.001$ \\
\hline $\begin{array}{l}\text { SF-36 physical role } \\
\text { functioning }\end{array}$ & $51.66 \pm 20.69$ & $86.66 \pm 12.68$ & $<0.001$ \\
\hline SF-36 pain & $47.33 \pm 17.20$ & $78.96 \pm 12.17$ & $<0.001$ \\
\hline $\begin{array}{l}\text { SF-36 general health } \\
\text { perceptions }\end{array}$ & $51.00 \pm 10.11$ & $80.00 \pm 9.73$ & $<0.001$ \\
\hline SF-36 vitality & $42.66 \pm 13.50$ & $81.16 \pm 10.22$ & $<0.001$ \\
\hline SF-36 social role functioning & $42.50 \pm 19.58$ & $79.16 \pm 16.19$ & $<0.001$ \\
\hline $\begin{array}{l}\text { SF-36 emotional role } \\
\text { functioning }\end{array}$ & $37.74 \pm 14.47$ & $78.86 \pm 18.54$ & $<0.001$ \\
\hline SF-36 SF 36 mental health & $34.66 \pm 12.75$ & $76.33 \pm 13.35$ & $<0.001$ \\
\hline
\end{tabular}

LSAS: Liebowitz Social Anxiety Scale; HADS: Hospital Anxiety and Depression Scale.

putation group compared to the control group (Table 1).

The patients who were amputated more than five years ago had higher depression scores when compared to the control group (HADS mean depression; 15.35 versus 3.18) $(p=0.006)$. The patients who were amputated more than five years ago had higher LSAS social fear scores, and lower HAD depression and HAD total scores compared to patients less than five years $(p=0.035, p=0.024, p=0.015$, respectively) (Table 2).

The patients with below knee amputation $(n=23)$ had lower HAD depression and HAD anxiety scores and higher SF-36 pain scores when compared to the patients with above-knee amputation $(n=7)(p=0.024, p=0.015, p=0.046$, respectively) (Table 3 ).

The employed patients $(n=15)$ had higher SF 36 pain and lower HAD depression and HAD total scores when compared to unemployed patients $(n=15)(p=0.024, p=0.008$, $p=0,049$, respectively).

The patients amputated due to medical complications
Table 2. Comparison of the psychiatric parameters based on time since amputation

\begin{tabular}{lccc}
\hline & $\begin{array}{c}<\mathbf{5} \text { years } \\
(\mathbf{n = 1 6 )}\end{array}$ & $\begin{array}{c}>\mathbf{5} \text { years } \\
(\mathbf{n = 1 4 )}\end{array}$ & $\mathbf{p}$ \\
\hline LSAS social fear & 14.5 & 17.7 & 0.035 \\
HADS depression & 17.6 & 15.3 & 0.024 \\
HADS total & 35.25 & 29.78 & 0.015
\end{tabular}

LSAS: Liebowitz Social Anxiety Scale; HADS: Hospital Anxiety and Depression Scale.

Table 3. Comparison of the HADS depression, HADS anxiety, and SF-36 scores based on the location of amputation

\begin{tabular}{lccc}
\hline & $\begin{array}{c}\text { Lower-knee } \\
(\mathbf{n}=\mathbf{2 3})\end{array}$ & $\begin{array}{c}\text { Above-knee } \\
(\mathbf{n = 7})\end{array}$ & $\mathbf{p}$ \\
\hline HADS depression & 15.95 & 18.71 & 0.024 \\
HADS anxiety & 14.91 & 19.0 & 0.015
\end{tabular}

HADS: Hospital Anxiety and Depression Scale; SF-36: Short-Form 36.

$(n=10)$ had higher scores in anxiety when compared to the patients with traumatic amputation $(n=20)(p=0.005$, $p=0.016$, respectively).

\section{Discussion}

In our study, the findings showed that patients with major limb extremity amputation had a higher severity of social phobia and depression and lower quality of life when compared to the control group.

Social phobia is one of the major problems for the rehabilitation of amputated patients ${ }^{[3,12-15]}$. Social phobia may often develop after amputation, and its severity may change over time. Horgan et al. ${ }^{[3]}$ reported that psychological problems related to physical appearance might cause social phobia after two years of amputation. The emergence of social phobia may also decrease the emotional competence of amputated patients, which is required for daily activities ${ }^{[3]}$. In addition, these problems may cause negative effects on the occupational and social lives of the patients ${ }^{[3,4]}$. In our study, LSAS social fear scores were higher in patients with amputation when compared to the control group. The patients with time since amputation of more than five years had higher scores in social phobia compared to the patients with time since amputation of fewer than five years. Therefore, we consider that amputated patients should be provided with prompt and sufficient psychiatric counseling.

Depression after amputation is another important problem for amputated patients ${ }^{[3,16]}$. Williamson et al. ${ }^{[17]}$ eval- 
uated the time since amputation in 160 amputated patients and reported that the frequency of depression was $21 \%$ in the patients with time since amputation of 2-10 years. A limited number of studies has shown that the depression rate increases after two years of amputation ${ }^{[3,}$ $15,17]$. In our study, depression scores were higher in all patients with amputation when compared to the control group. However, the patients with time since amputation of more than five years had lower scores in depression compared to the patients with time since amputation of less than five years, which suggests that the person has been partially successful in dealing with depression by accepting his current situation over the years. However, we may argue that depression remains a severe problem after five years of amputation.

The level of amputation is also an important factor for social phobia and depression. Hagberg et al. ${ }^{[18]}$ reported that adaptation to prosthesis and performance in daily activities provided lower scores in the patients with above-knee amputation when compared to the patients with lower knee amputation. In our study, the patients with lower knee amputation had significantly lower scores in depression and anxiety compared to the patients with above-knee amputation. We think that the higher severity of depression and anxiety in the patients with above-knee amputation, when compared to the patients with lower knee amputation, is because it is more difficult to adapt to prosthesis and daily life activities in the light of the literature. Thus, we consider that psychiatric counseling should be prioritized in patients with above-knee amputation.

Occupational life is a component of social rehabilitation after amputation ${ }^{[3,19,20]}$. Rybarczyk et al. ${ }^{[19]}$ evaluated 89 amputated patients and reported that social life is closely associated with depression. In our study, the severity of social phobia and depression was significantly lower in employed patients when compared to unemployed patients. Sustaining a permanent occupation might have a positive effect on the wellbeing of an amputated patient. Hence, we may conclude that providing permanent employment opportunities for amputated patients and redesigning the workplaces according to their needs are of prime importance.

A limited number of studies is available that compare the patients with traumatic amputation with the patients due to medical complications ${ }^{[3,21]}$. Previous studies showed that adaptation to amputation and social rehabilitation was more challenging for the patients amputated due to systemic diseases ${ }^{[3,21-23]}$. Jayakaran et al. ${ }^{[23]}$ evaluated 12 patients with lower knee amputation (due to medical complications [n=6] and traumatic causes [n=6]) and reported that anxiety scores were significantly higher in the patients amputated due to medical complications. Similarly, we also found that the anxiety scores were higher in the patients amputated due to medical complications. Thus, our findings are consistent with the literature ${ }^{[15]}$.

It is expected that the quality of life will deteriorate in patients with major amputation ${ }^{[15,24]}$. Smith et al. ${ }^{[25]}$ reported negative effects of low back pain, phantom pain, and stump pain on quality of life after lower limb amputations. Ebrahimzadeh et al. ${ }^{[26]}$ reported that psychiatric problems, as well as low back pain, phantom pain, age and employment, affect the quality of life. Hagberg et al. ${ }^{[18]} \mathrm{re-}$ ported that the level of amputation affects daily life activities. In our study, all quality of life subscales were found to be lower in patients with amputation compared to the control group. In the light of the literature, we think that the quality of life in patients with major lower extremities has deteriorated due to many factors, such as psychiatric problems, low back pain, phantom pain, stump pain, age, level of amputation, adaptation to prosthesis and employment.

The limitations of our study are the small number of patients and its retrospective design. More definitive results can be obtained with a larger number of patients and prospective studies.

\section{Conclusion}

Social phobia, depression and poor quality of life are common problems in patients with major lower limb amputation. After five years, it should not be forgotten that social phobia will increase and depression will decrease along with its seriousness. Therefore, amputated patients should be psychiatric counseled and treated. It is important to provide permanent employment opportunities to improve the quality of life.

Ethics Committee Approval: The Ethics Committee of Health Sciences University Istanbul Medeniyet University Göztepe Training and Research Hospital provided the ethics committee approval for this study (10.04.2019-2019/0125).

Peer-review: Externally peer-reviewed.

Authorship Contributions: Concept: I.A., Y.T.; Design: A.D., I.A.; Data Collection or Processing: I.S., E.O.; Analysis or Interpretation: A.D., M.G.; Literature Search: Y.T., E.O.; Writing: A.D., E.O.

Conflict of Interest: None declared.

Financial Disclosure: The authors declared that this study received no financial support. 


\section{References}

1. Mazurek M, Helmers S. Lower extremity amputations. In: Flynn JM (editor). Orthopaedic knowledge update 10. Philadelphia: AAOS, 2011: 537-45.

2. Toy PC. General principles of amputations. In: Canale ST, Beaty JH (editors). Campbell's operative orthopaedics. Vol. 1, 12th ed. Philadelphia: Mosby, Elsevier, 2013: 598-637. [CrossRef]

3. Horgan O, MacLachlan M. Psychosocial adjustment to lowerlimb amputation: a review. Disabil Rehabil 2004;26:837-50.

4. Bodenheimer C, Kerrigan AJ, Garber SL, Monga TN. Sexuality in persons with lower extremity amputations. Disabil Rehabil 2000;22:409-15. [CrossRef]

5. Topçuoğlu V, Bez Y, Sahin Biçer D, Dib H, Kuşçu MK, Yazgan C, et al. Essansiyel Tremorda Sosyal Fobi. Turk Psikiyatri Derg 2006;17:93-100.

6. Ferguson AD, Richie BS, Gomez MJ. Psychological factors after traumatic amputation in landmine survivors: the bridge between physical healing and full recovery. Disabil Rehabil 2004;26:931-8. [CrossRef]

7. Dilbaz N. Liebowitz Sosyal Kaygı Ölçeği Geçerlilik ve Güvenilirliği. Proceedings of the 37th National Congress of Psychiatry; İstanbul: Turkey; 2001; 132.

8. Zigmond AS, Snaith RP. The hospital anxiety and depression scale. Acta Psychiatr Scand 1983;67:361-70. [CrossRef]

9. Aydemir Ö. Hastane Anksiyete ve Depresyon Ölçeği Türkçe Formunun Geçerlilik ve Güvenilirlik Çalışması. Turk Psikiyatri Dergisi 1997;8:280-87.

10. Ware JE Jr, Sherbourne CD. The MOS 36-item short-form health survey (SF-36). I. Conceptual framework and item selection. Med Care 1992;30:473-83. [CrossRef]

11. Koçyiğit H, Aydemir Ö, Ölmez N, Memiş A. Kısa Form 36 (KF36)'nın Türkçe versiyonunun güvenilirliği ve geçerliliği. İlaç ve Tedavi Dergisi 1999;12:102-6.

12. Rybarczyk B, Behel J, Szymanski L. Limb amputation. In: Frank RG, Rosethan M, Caplan B (editors). Handbook of Rehabilitation Psychology. 2nd ed. Washington DC: American Psychological Association, 2010: 29-42. [CrossRef]

13. Dunn DS. Social psychological issues in disability. In: Frank RG, Rosethan M, Caplan B (editors). Handbook of Rehabilitation Psychology. 2nd ed. Washington DC: American Psychological Association, 2010: 379-90.
14. Gething L. Generality vs. specificity of attitudes towards people with disabilities. Br J Med Psychol 1991;64:55-64. [CrossRef]

15. Dziadosz DR, Bergmann KA. Lower extremity amputations. In: Cannada LK (editor). Orthopaedic knowledge update 11. Rosemont: AAOS, 2014: 659-75.

16. Williams RM, Ehde DM, Smith DG, Czerniecki JM, Hoffman AJ, Robinson LR. A two-year longitudinal study of social support following amputation. Disabil Rehabil 2004;26:862-74. [CrossRef]

17. Williamson GM, Schulz R, Bridges MW, Behan AM. Social and psychological factors in adjustment to limb amputation. Journal of Social Behavior and Personality 1994;249-68.

18. Hagberg E, Berlin OK, Renström P. Function after throughknee compared with below-knee and above-knee amputation. Prosthet Orthot Int 1992;16:168-73. [CrossRef]

19. Rybarczyk B, Nyenhuis DL, Nicholas JJ, Cash SM, Kaiser J. Body image, perceived social stigma, and the prediction of psychosocial adjustment to leg amputation. Rehabilitation Psychology 1995;49:95-110. [CrossRef]

20. Pezzin LE, Dillingham TR, Mackenzie EJ, Ephraim P, Rossbach P. Use and satisfaction with prosthetic limb devices and related services. Arch Phys Med Rehabil 2004;85:723-9. [CrossRef]

21. Whylie B. Social and psychological problems of the adult amputee. In: Kostuik JR, Gillespie J (editors). Amputation Surgery and Rehabilitation: The Toronto Experience. New York: Churchill Livingstone, 1981: 387-93.

22. Randall GC, Ewalt JR, Blair H. Psychiatric Reaction to Amputation: Lieutenant Colonel Guy C. Randall Medical Corps, Army of the United States. Journal of the American Medical Association 1945;128:645-52. [CrossRef]

23. Jayakaran P, Johnson GM, Sullivan SJ. Turning performance in persons with a dysvascular transtibial amputation. Prosthet Orthot Int 2014;38:75-8. [CrossRef]

24. Hagberg K, Brånemark R. Consequences of non-vascular trans-femoral amputation: a survey of quality of life, prosthetic use and problems. Prosthet Orthot Int 2001;25:186-94. [CrossRef]

25. Smith DG, Ehde DM, Legro MW, Reiber GE, del Aguila M, Boone DA. Phantom limb, residual limb, and back pain after lower extremity amputations. Clin Orthop Relat Res 1999;(361):29-38.

26. Ebrahimzadeh $\mathrm{MH}$, Fattahi AS. Long-term clinical outcomes of Iranian veterans with unilateral transfemoral amputation. Disabil Rehabil 2009;31:1873-7. [CrossRef] 